\title{
A Roman altar on Mount Gerizim: Rediscovering a civic icon on tetradrachms of Neapolis (Samaria)
}

\author{
Andreas J. M. Kropp \\ Department of Classics and Archaeology, University of Nottingham \\ <andreas.kropp@nottingham.ac.uk>
}

\begin{abstract}
This article examines the iconography of a type of Caracalla tetradrachm that has been newly attributed to Neapolis in Roman Palestine and whose reverse depicts a monumental altar decorated with statues of Tyche, Ephesian Artemis, and Kore Persephone. The study contextualizes these deities in the religious life of Neapolis and identifies the monument as an altar often depicted as a miniscule element in panoramic views of Mount Gerizim on the bronze coins of Neapolis. The tetradrachms provide, for the first time, a close-up view of this long-lost civic monument.
\end{abstract}

Keywords: Numismatics, tetradrachms, monumental architecture, Tyche, Palestine, Neapolis (Samaria)

Silver tetradrachms were the main regional currency in Roman Syria and the Near East from the establishment of Roman power in the 1st c. BCE until the end of production in the mid-3rd c. CE. ${ }^{1}$ These large, thick coins of typically 11-15 gm weight played a key role in the regional economy. In a world where everyday transactions were done with bronze coins produced locally and whose reach and monetary value were limited to their respective territories, tetradrachms transcended local particularism as universally accepted legal tender and the currency of choice for large transactions. Scholarship on tetradrachms is in many ways only in its initial stages: compared to other ancient coinages, technical issues such as mint attributions, coin output, and circulation are still poorly understood.

My focus here is not on such strictly numismatic questions, but rather on the imagery on these coins. Such an iconographic approach is unusual for this kind of medium: the vast majority of tetradrachms adopt a rigid and monotonous design formula repeated ad infinitum, and consequently the coins have attracted virtually no interest from art-historically minded experts. But here I will draw attention to a rare "special edition" tetradrachm type from Roman Neapolis with unique imagery on its reverse that will be of interest to Roman archaeologists and students of the Roman Near East. The coin type depicts a monumental altar decorated with statues of Tyche, Ephesian Artemis, and Kore Persephone. An iconographic analysis will contextualize these figures in the religious life of Neapolis. As the coin type was issued jointly with three other types in a special emission of tetradrachms celebrating the civic icons of Neapolis, the monument can be identified as an altar often seen, but so far only known as a minuscule structure, in landscape views of Mount Gerizim on the bronze coins of Neapolis. The tetradrachms provide, for the first time, a close-up view of this long-lost civic monument.

Standard references: Bellinger 1940; Prieur and Prieur 2000. 

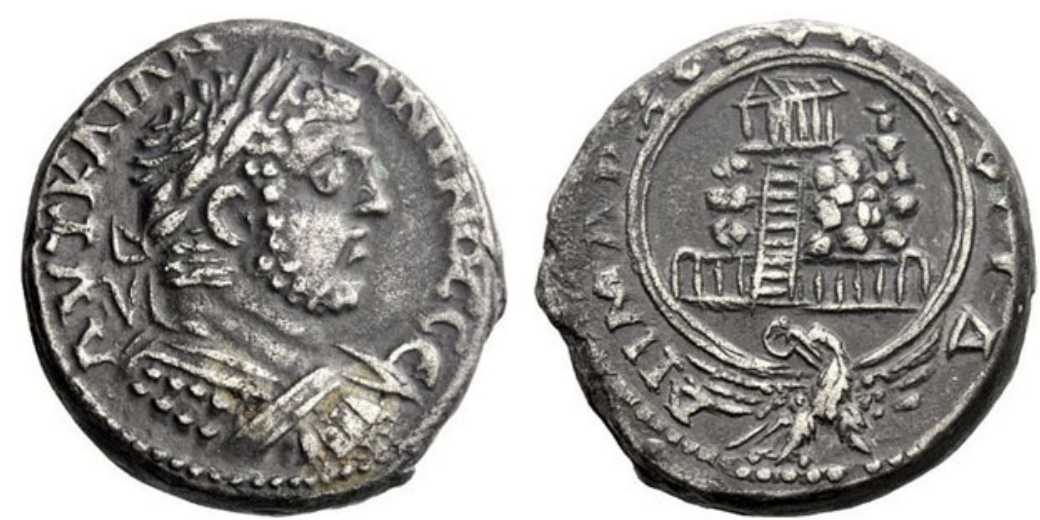

Fig. 1. Tetradrachm of Caracalla minted at Neapolis, 215-17 CE (26 mm, $13.3 \mathrm{gm})$, shown twice actual size in print. Bust / Mount Gerizim within double circle, supported by eagle facing. (ANS 1944.100.69115. American Numismatic Society.)

\section{New attribution to Neapolis}

The attribution of this coin type to Neapolis is a new development made possible by the discovery of a new die link (see below). Identifying the many issuing mints of Caracalla tetradrachms is generally not easy, and many tetradrachms still defy attribution. Antioch was for a long time by far the most productive and often the sole mint, but under Caracalla (212-17 CE) production took off on a massive scale and across some two dozen mints in Cilicia, Syria, Phoenicia, and Palestine. But the coins are almost devoid of any reference to their mints. They always show the emperor's bust on the obverse and list his name and titles in Greek on both sides. The reverse is, regardless of the mint, almost invariably taken up by a large Roman eagle in frontal view with outstretched wings, head to one side, and a wreath in its beak. The only reference to the mint's identity is usually a tiny symbol (the so-called "mintmark") between the eagle's talons like the small altar in Figure 2. Very often these symbols are indistinct and rather generic (e.g., star, crescent, altar) and give rise to endless debates about possible attributions to mints. ${ }^{2}$

Attributions are further impeded by the distinct monetary characteristics of tetradrachms: As a regional currency, tetradrachms traveled far and wide. Hence, in tetradrachm hoards, unlike bronze hoards, different groups of coins are often mixed at random with no conspicuous preference for coins from nearby mints. Also, there are no known die links between different groups of tetradrachms, or between tetradrachms and local bronze coinage, which could aid attribution. This explains why the state of research on mint attributions is essentially where it was 80 years ago when A. J. R. Bellinger published his handbook, which is still the only standard reference on Roman tetradrachms alongside M. and K. Prieur's catalog. ${ }^{3}$

2 On methodological problems in tetradrachm studies, see Butcher 2004, 109-16; Amandry 2016; Kropp 2021.

3 Bellinger 1940. Prieur and Prieur 2000, who explicitly follow Bellinger's lead: “No attempt has been made to reattribute issues, although many attributions are dubious or imprecise" (vii). 

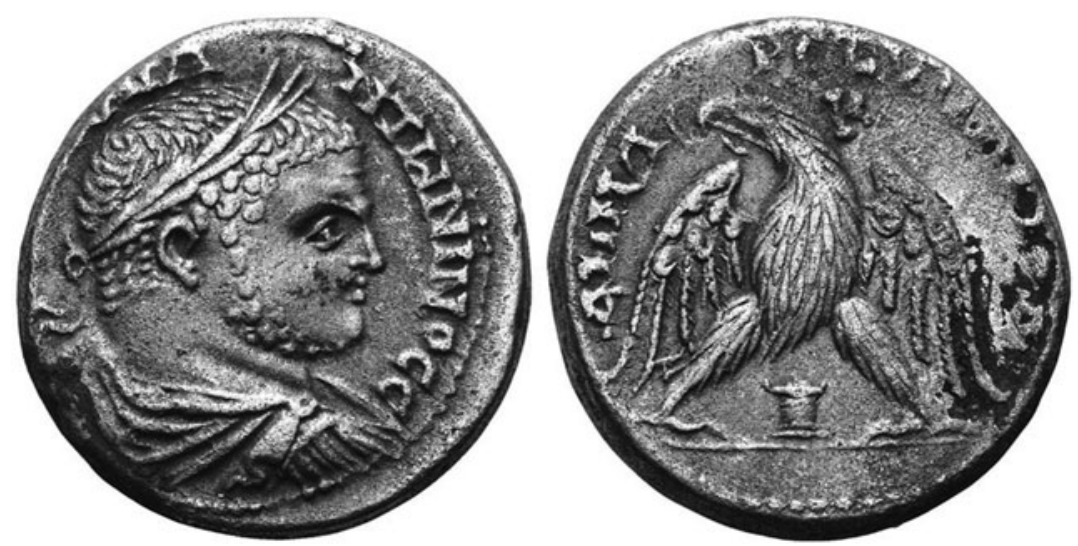

Fig. 2. Tetradrachm of Caracalla minted at Neapolis, 215-17 CE (27 mm, $12.2 \mathrm{gm})$, shown twice actual size in print. Bust / Eagle standing facing, small altar between talons. (Bibliothèque Nationale de France Y 19622.)

The four coins presented here (Figs. 1-4), each with a different kind of mintmark, are a case in point. They have until now been attributed to two different cities, Neapolis in Palestine and Byblos in Phoenicia. One type shows a panoramic view of Mount Gerizim (Fig. 1), the sacred mountain of the Samaritans that adjoined Roman Neapolis in Palestine. This is a motif very often seen on coins of Neapolis and hence identifies the issuing mint with certainty. ${ }^{4}$ The other three types show altars of various sizes: small, large, and extra-large (Figs. 2-4). ${ }^{5}$ Of these, only the coins with the small altar mintmark (Fig. 2) were known to Bellinger at the time. With the tiny altar mintmark on the reverse his only clue, he found altars of comparable shape on the bronze coins of Byblos and, on the strength of this comparison alone, attributed the tetradrachms to Byblos. As the large and extra-large altars became known, Bellinger's successors followed suit with the same attribution. The frailty of this identification is evident, but the attribution is universally accepted today and perpetuated without question in museum, collection, and sales catalogues.

This attribution can now be shown to be incorrect thanks to a newly discovered obverse die link between coins bearing these four different reverse types. ${ }^{6}$ The obverse die shared between these coins connects the reverse types with one another and thus places them all at the same mint. Given the secure identification of Mount Gerizim on one of the reverses, these tetradrachms can now all be attributed to Neapolis. The Roman tetradrachm mint of Byblos, listed in all the standard references, probably never existed. Since the pioneering days of Bellinger, this is the first secure new attribution of any group of Caracalla tetradrachms, a fact that not only underlines the rarity of such die links to aid our attributions, but also shows the impact that the discovery of one rare piece of irrefutable evidence can have on our understanding of this coinage.

4 Bellinger 1940, 93-94; Prieur and Prieur 2000, no. 1700.

5 Bellinger 1940, 78-79; Prieur and Prieur 2000, nos. 1307-8, 1315.

6 See full discussion and illustrations in Kropp 2021. Illustrations of the die link cannot be reproduced in this venue due to $J R A$ policy restrictions on antiquities whose provenance cannot be traced back to before 1970 . 

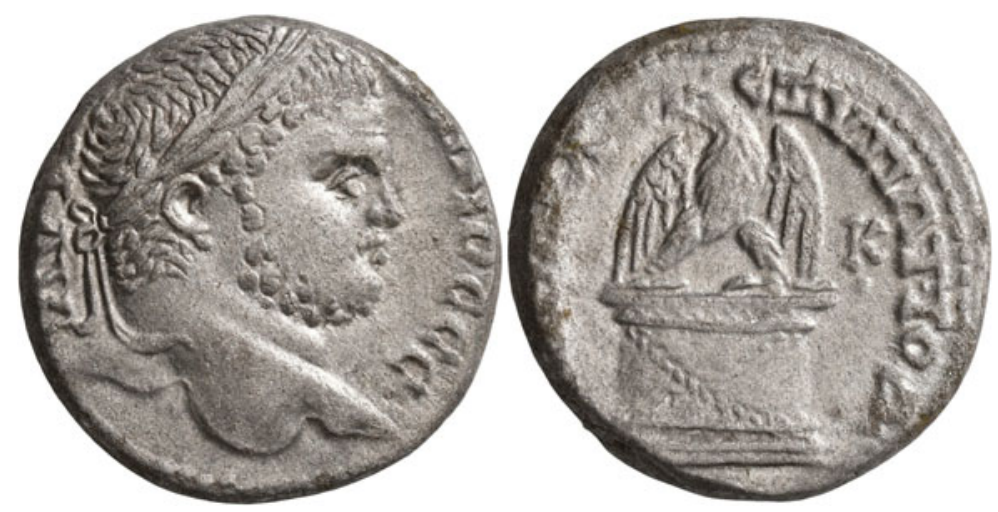

Fig. 3. Tetradrachm of Caracalla minted at Neapolis, 215-17 CE (25 mm, $11.3 \mathrm{gm})$, shown twice actual size in print. Bust / Eagle perched on large altar. (Bibliothèque Nationale de France 1989.212.)
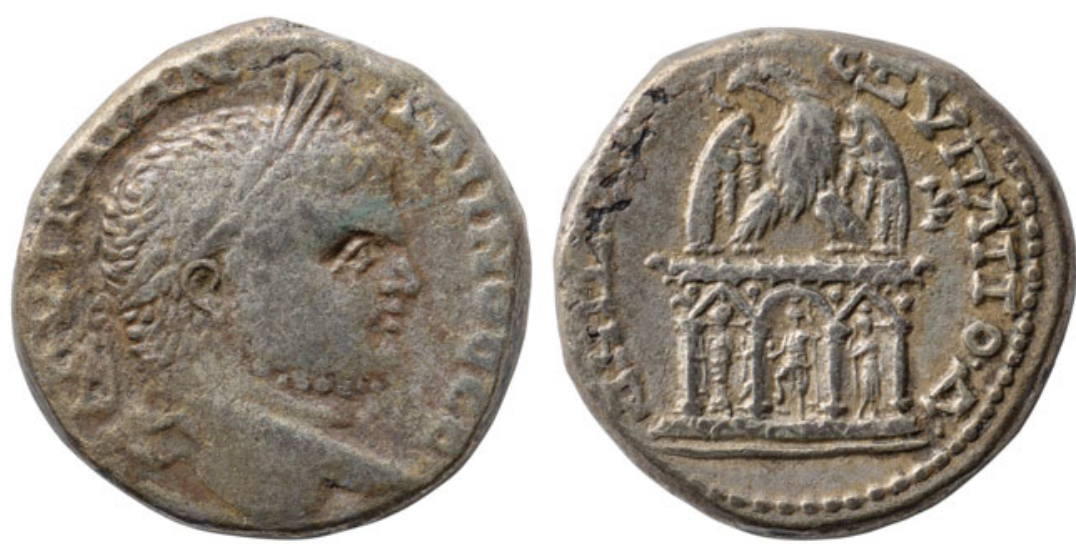

Fig. 4. Tetradrachm of Caracalla minted at Neapolis, 215-17 CE (26 mm, $13.1 \mathrm{gm})$, shown twice actual size in print. Bust / Eagle perched on monumental altar. (Bernisches Historisches Museum, Bern, inv. no. 82.2368. Photo: Christine Moor. Reproduced with permission.)

\section{The architecture: a monumental altar}

The present article builds on this new attribution and turns to the imagery on these coins. As mentioned above, the design formula of Roman tetradrachms is usually rigid and monotone: imperial portrait, names, and titles; Roman eagle; tiny mintmark (Fig. 2 is a typical example). The "special edition" tetradrachms with enlarged and prominent mintmarks such as Mount Gerizim and the extra-large altar (Figs. 1, 4) are hence exceptionally rare. Several mints have such special editions in their repertoire, often showing a second imperial bust on the reverse being carried by an eagle, plus the mintmark, but they were produced in extremely limited quantities. Prieur and Prieur consider this special coinage to be "presentation issues," i.e., the first issues to be struck at each respective mint to celebrate its inauguration. ${ }^{7}$ Their catalog is sorted accordingly: special edition issues are 
consistently at the top of the list for their respective mints, suggesting that they were issued first. There is however, for lack of in-depth die studies, no solid chronological evidence to suggest that these were indeed inaugural issues. They could have been minted at any point, perhaps, for example, to celebrate special occasions. ${ }^{8}$

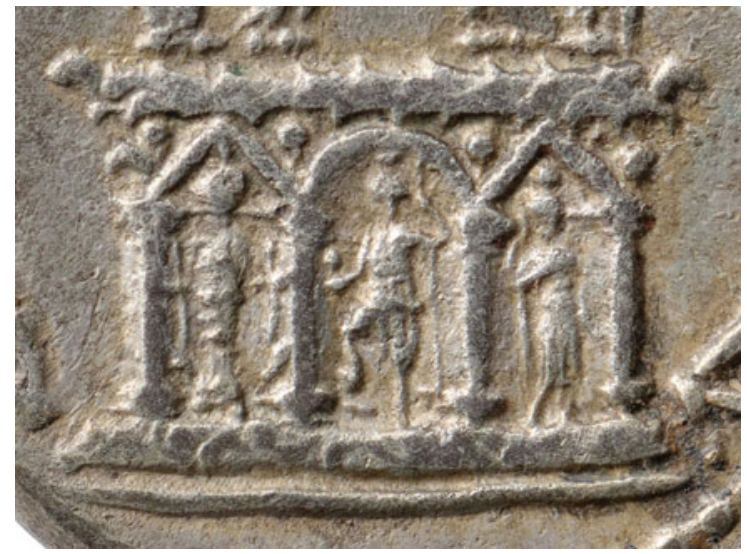

Fig. 5. Detail of the reverse of the tetradrachm in Fig. 4.

The extra-large altar appears especially interesting, as it depicts an unknown monument with considerable detail. One specimen of this type (Figs. 4-5) was briefly presented by B. Kapossy in $1988{ }^{9}$ it is part of the F. Righetti collection that was bequeathed to the coin cabinet of the Historisches Museum in Bern. ${ }^{10}$ This coin was catalogued by Prieur and Prieur and classified under Byblos. ${ }^{11}$ Beyond these two references, the type has, to my knowledge, gone unnoticed. Three more specimens have since appeared on the market. ${ }^{12}$ Of the four known coins, one shares its obverse die with the types discussed above. The other three share both obverse and reverse dies with each other.

For my description of the structure I will mostly use the shared reverse die (Figs. 4-5), with reference to the second, cruder die where it deviates. ${ }^{13}$ The depicted structure rests on a molded two-tiered base (three tiers on the other die) and is divided by columns into three sections, each containing one full-length standing figure. The middle section has a rounded top, the others triangular ones. These appear to be niches carved into a wall: In the central niche, the back wall is shown in rounded shape receding gradually into depth toward the center; the top of this niche is rendered in a half-dome shape. The "columns" are then in fact pilasters. The side niches have horizontal lines that run behind the figures' heads connecting one pilaster capital with the other across the breadth of the niche; they seem to indicate an entablature. In the spandrels above the niches, one dot for each spandrel indicates some kind of decoration. The entablature on top is decorated with a zigzag line interspersed with dots. In sum, the structure is presented as one solid block with niches but without openings. It is not a temple façade or a monumental gateway, but rather a monumental altar, as shown by comparisons with other coins (see Fig. 6) and by analogy with the other tetradrachm types linked to this one (Figs. 2-3).

With its unusual architectural features, this monument stands out from other tripartite structures - likewise populated by trios of figures - that frequently appear on civic coins in

See Nurpetlian 2014, 191.

Kapossy 1988.

Published in the collection catalogue Kapossy 1993, no. 2368.

Prieur and Prieur 2000, no. 1308.

CNG, Triton XVII, lot 759, sold January 14, 2014; auction 99, lot 491, sold May 13, 2015; auction 112, lot 437, sold September 11, 2019.

$13 \quad$ For illustrations, see Kropp 2021. 

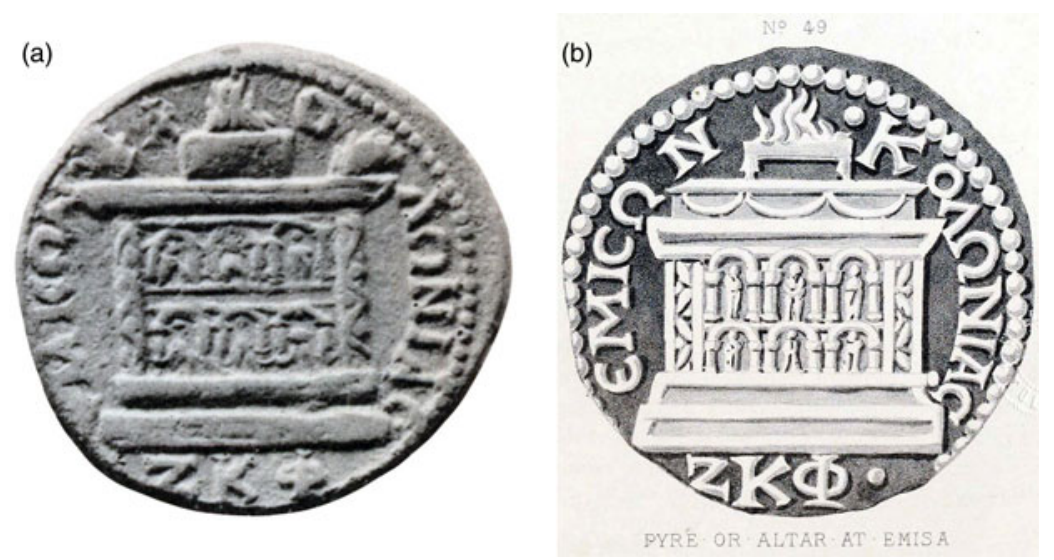

Fig. 6. Civic bronze of Emesa minted under Caracalla, 215/16 CE (24 mm, $12.6 \mathrm{gm})$, shown twice actual size

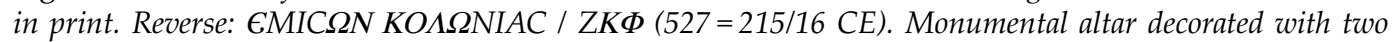
rows of niches with statues; small altar with flames above. (British Museum Dept. of Coins and Medals 1840,1226.456). (a) Photo (Wroth 1910, pl. 27.11.); (b) Drawing (Donaldson 1859, no. 49.)

the Roman Near East: in Phoenicia and Palestine, in particular, tripartite, temple-like structures with three standing figures are very common. With their colonnaded, usually tetrastyle, fronts and pedimented roofs, most of these structures can be identified as temple façades, though this may not always be the case. Many examples from Phoenicia show adventurous designs with improbable combinations of entablatures, gables, and arches, and seem to depict something else, which some would interpret as representations of adyta, i.e., inner shrines inside temples. Architecturally, none of these structures matches our Neapolis tetradrachms, but the comparison is useful for one important feature they do share, namely the arrangement of figures with Tyche in the middle, thus putting the city's patron goddess front and center and focusing on messages that are relevant to the community as a whole.

Decorated, monumental altars are not often depicted as free-standing monuments on their own on Near Eastern civic coins. The most prominent example is on the civic coins of Emesa minted under Caracalla, at the same time as our tetradrachms (Fig. 6). ${ }^{14}$ The reverse shows an altar, no doubt from the sanctuary of Elagabal, set on a two-tiered base and crowned by an entablature. The main panel is decorated with two sets of three niches containing figures. One notes parallels with the Neapolis altar in the overall structure and proportions, as well as the statue niches filling in the entire panel.

On top of the Emesa altar one sees a cubic structure from which flames are rising, sometimes flanked by animal acroteria at the corners. This cube is the actual sacrificial altar placed on top of the altar monument. The small size of the sacrificial altar gives a good idea of the enormous size of the monument. Several real-life versions of monumental altars, which one could access and ascend via internal staircases, are known from the Roman Levant, for example at Baalbek. ${ }^{15}$ The arrangement with a monumental altar

$14 \quad$ Price and Trell 1977, fig. 301; Baldus 2001, nos. 814-15; Nurpetlian 2020, 172-74, no. 33. The altar is also shown on a smaller denomination, a very rare type under Elagabalus: see Nurpetlian 2020, 181, no. 45.

15 Butcher 2003, 355-56. 
serving as platform for a normal-sized sacrificial altar on top, is also not unheard-of in the sacred architecture of the Classical world, with the best-known example the Great Altar at Pergamon. Unfortunately, details of the sacrificial altar are missing from the Neapolis tetradrachm due to constraints of space and the eagle placed right on the flat top of the altar. But given that this altar was similarly decorated with what are likely statues in niches, and by virtue of analogy with Emesa, one can surmise that it too was a building of considerable dimensions that was surmounted by a normal-sized sacrificial altar.

\section{The figures: Tyche, Ephesian Artemis, and Kore}

The engravers of these Neapolis tetradrachms went to great lengths to make the three figures recognizable despite their minute size (Fig. 5). The central figure is Tyche, in this case the local patron goddess of Neapolis. Like most Tyches of Roman Palestine, she is modeled after the Tyche of Caesarea Maritima. ${ }^{16}$ She is shown standing in a frontal position, with her head turned to her right, gazing at a bust in her outstretched right hand. She is wearing a mural crown, a short peplos with apoptygma, and a mantle hanging over the left arm, parazonium at the side. Her right foot is raised, resting on a prow. The long staff in her left hand is too indistinct to be identifiable, but it is in all likelihood meant to be a stylis, a short mast with cross-bar at the top, made to be set on the prow of a ship. With her short tunic, sword, and masculine stance, this Tyche has a distinctly Amazonian iconography, adopted from images of the goddess Dea Roma (and/or Virtus, whose iconography is identical). Combined with the bust of the emperor in her hand, she conveys a message of allegiance to Rome.

At Neapolis, the civic bronze coinage consistently shows two types of Tyche. ${ }^{17}$ A Tyche of what appears to be a variant of the Caesarean type appears under Antoninus Pius in 160/61 CE. ${ }^{18}$ She is depicted standing frontally, wearing an Amazonian short tunic and a kalathos on her head, framed by a tetrastyle architectural façade. At her left foot there appears to be a small figure. But unlike the Tyche of Caesarea, both her feet are flat on the ground, and in her right hand she is holding a long scepter. Contemporary with this coinage, Tyche is shown in different guise on coins with Faustina Minor on the obverse: dressed in a long robe, head in profile wearing a kalathos, and holding a rudder and cornucopia. ${ }^{19}$ Then under Commodus the other Tyche appears again, this time with all the features of the Caesarea type. ${ }^{20}$ From then on, both types remain in use side by side.

On the tetradrachm altar, the figure in the left niche would be hard to discern on its own, but can be identified with the help of Neapolitan civic coinage: it is the Artemis of Ephesos, frequently depicted on Neapolitan bronze. ${ }^{21}$ Neapolis is unusual in this respect: to my knowledge, no other city in the Roman Near East (Syria, Phoenicia, Palestine, Arabia) put her on its civic coins. On our tetradrachms Artemis is depicted with her key

16 Gersht 1984; for more recent literature, see Kropp 2011, 391.

17 For Neapolis coins, I will refer above all to the superb Sofaer Collection at the Israel Museum, published in Meshorer 2013, which "includes the most comprehensive corpus [of] Neapolis coins" (50), including unique and unpublished types.

18 Meshorer 2013, no. 29.

19 Meshorer 2013, nos. 45-46, 48, 52-54.

20 Meshorer 2013, no. 64.

${ }^{21}$ Meshorer 2013, nos. 47, 49-51, 58-59, 66-67, 118-19, 126-27. 

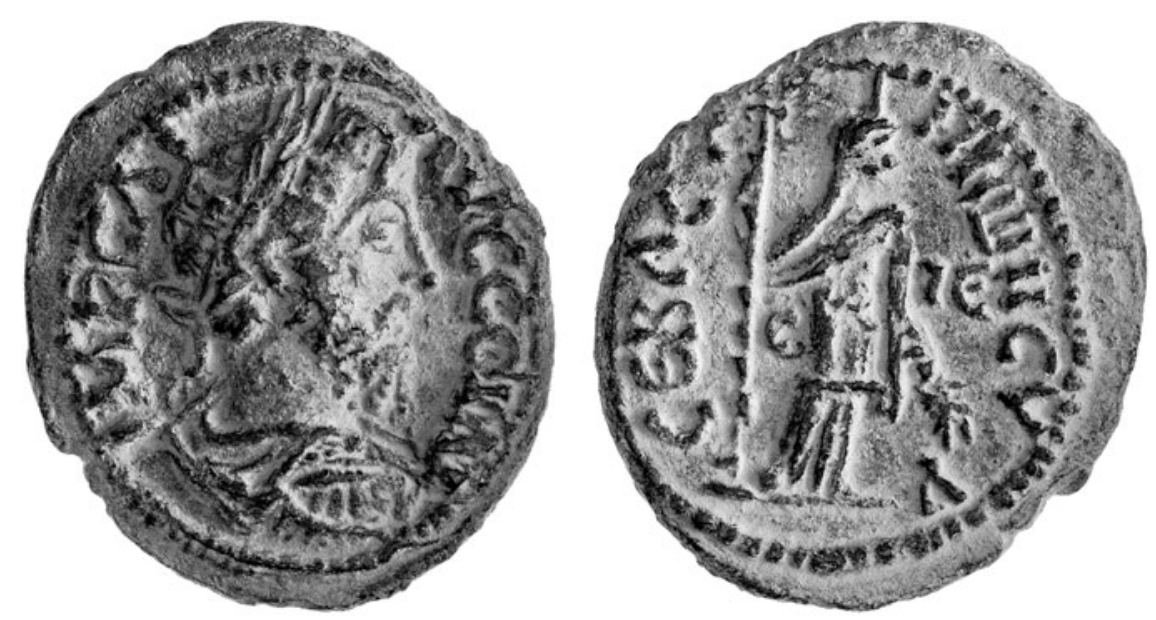

Fig. 7. Civic bronze of Sebaste minted under Commodus, 187/88 CE (30 mm, $13.1 \mathrm{gm})$, shown twice actual size in print. Draped bust / Kore standing r., wearing kalathos on head, holding ears of grain and long torch. (From the Sofaer Collection at The Israel Museum. Photo (C) American Numismatic Society. Reprinted with permission.)

features, as an ancient idol standing stiffly upright, wearing a kalathos on her head. ${ }^{22}$ One can just see her forearms jutting out horizontally from her torso. From her hands there are vertical lines toward the ground; these are presumably the woolen fillets. The Ephesian Artemis is known for her distinct tight-fitting apron (ependytes), which is decorated with busts and animal protomes. On the coins these are rendered with tiny dots. Her acolytes, normally one stag to either side, are barely discernible.

The figure in the right niche is Kore Persephone. Bronze coins from Neapolis once again offer comparanda, but my first comparison is with very clear images of this goddess on coins from neighboring Sebaste (Fig. 7), where a cult of Kore is well attested. ${ }^{23}$ These coins, as well as a marble statue found at the stadium of Sebaste, show Kore with the same distinct posture and costume. ${ }^{24}$ On the tetradrachm, one can discern a female figure standing in frontal position wearing a tall headdress. She is dressed in a chiton falling to her feet, a peplos falling to below her knees, and a veil. She is standing in a slight contrapposto pose, with the weight resting on her left foot, and her right foot slightly drawn to one side. Her right forearm looks as if it is bent, with her right hand resting on her chest. Yet at the same time, one can see a staff to the left of the figure, seemingly running into her right elbow, which she must be holding in some way. This contradiction became clear to me once I saw the Sebaste coins: the "hand" on the chest is really an unusually thick bunch of folds of her veil bulging over her chest and drawn to her right elbow in a diagonal line. The figure's right arm is actually raised and holding the staff with the right hand. Once this is clear, one can also see the very slender forearm rising alongside the staff. The spindly right forearm is a recurring feature of coin images of Kore, at Sebaste, Neapolis (Figs. 8-10), and elsewhere. The correspondences in iconographic details between the coin images are

22 On the iconography of Artemis of Ephesos, see Fleischer 1973.

23 Meshorer 2013, nos. 14-18, 20-21, 28-29, 32, 34-35, 39. On the cult of Kore at Sebaste, see Magness 2001; Ovadiah and Mucznik 2009, 136-41.

24 For the statue, see Magness 2001, 160-61, fig. 3; Ovadiah and Mucznik 2009, 137, fig. 241. 


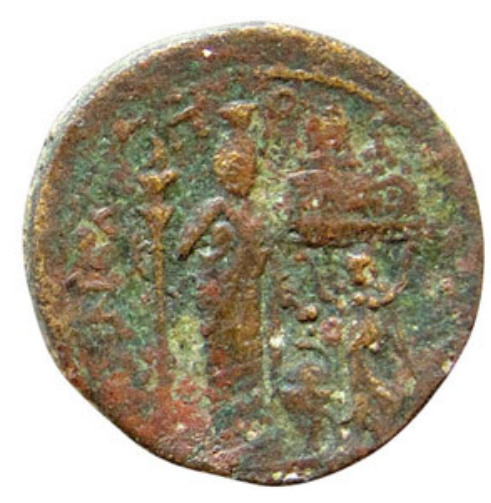

Fig. 8. Civic bronze of Neapolis minted under Volusian, 251-53 CE (24 mm, 9.0 gm), shown twice actual size in print. Reverse: Kore standing, holding long torch entwined by serpent; at right, Nike supporting a model (?) of Mount Gerizim. (Yale University Art Gallery 2001.87.12652.)

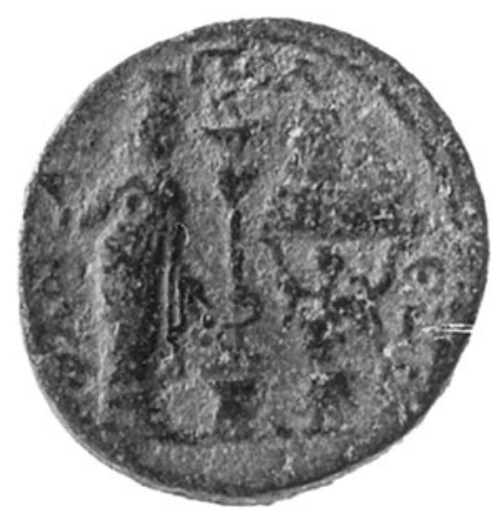

Fig. 9. Civic bronze of Neaplos minted under Trebonianus Gallus, 251-53 CE (25 mm, 11.9 gm), shown twice actual size in print. Reverse: Kore standing, flanked by long torch entwined by serpent; at right, long torch, cista mystica, Nike supporting a model (?) of Mount Gerizim. (From the Sofaer Collection at The Israel Museum. Photo (C) American Numismatic Society. Reprinted with permission.)

close enough, and at the same time these features are distinct enough from other deities, to be able to identify the figure as Kore Persephone. The staff in her right is then a long torch, and in her left she was probably meant to be holding grain ears.

Kore Persephone and her mother, Demeter, the goddesses of Eleusis and the Eleusinian mysteries, are well attested in the Levant. Evidence is concentrated especially in the south, in Palestine and to a lesser extent Phoenicia and Arabia, but almost absent from northern Syria, except at Antioch. This distribution may indicate that Egypt, and more particularly Alexandria, where mystery cults remained very popular throughout antiquity, was the likely source of the spread of Eleusinian cults in the Levant, where they may have been assimilated to existing local cults. ${ }^{25}$

In the following, I will address Kore Persephone only as Kore, as this is how she is usually identified in Roman times. Kore appears regularly on coins of Ptolemais, Caesarea, Skythopolis, Diospolis, and Sebaste, either as a standing figure, sometimes together with Demeter, or in a narrative scene being abducted by Hades. ${ }^{26}$ When mother and daughter are depicted on coins standing side by side, they are virtually identical: for example, on coins of Ptolemais, Kore and Demeter mirror each other in posture and attributes; they both wear kalathoi and hold snake-entwined torches. ${ }^{27}$

25 Seyrig 1932, 357-60.

26 Ptolemais: Meshorer 2013, nos. 200, 216-17, 249, 261, 264-65, 284-85; Caesarea: Meshorer 2013, nos. 47(?), 67, 97, 101, 106-7, 115, 138, 156-57; Skythopolis: Meshorer 2013, nos. 30-31, 70-71; Diospolis: Meshorer 2013, nos. 2, 14; Farhi 2007-8, 160-61, no. 5. Farhi 2007-8, 158, casts doubt on one type which is only known from one worn specimen, but the reading in Meshorer 2013, no. 14, appears to be correct, and Eleutheropolis (Farhi's alternative suggestion) does not have such a reverse type. 


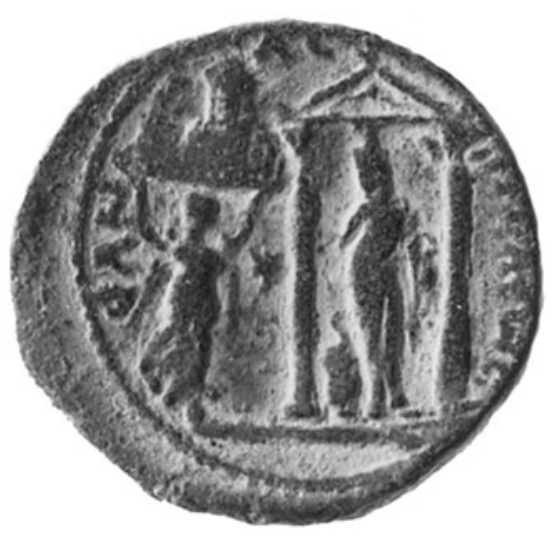

Fig. 10. Civic bronze of Neapolis minted under Trebonianus Gallus, 251-53 CE (26 mm, 11.0 gm), shown twice actual size in print. Reverse: Kore standing in distyle shrine next to cista mystica; at left, Nike supporting a model (?) of Mount Gerizim. (From the Sofaer Collection at The Israel Museum. Photo (C) American Numismatic Society. Reprinted with permission.)
This means that, for images where only one of them appears, it is impossible to tell on purely iconographic grounds whether it is one or the other. But there are good reasons to consider Kore the more likely option: first, the narrative scenes depicted on these city coins involving the Eleusinian goddesses are focused on the story of Persephone. Her abduction to, and seasonal return from, the underworld takes center stage and was evidently deemed worth conveying and promoting, to such an extent as to have it put on the city's official currency. The story evokes symbolic connotations about death and regeneration, concepts of essential value to initiates into the mystery cults. ${ }^{28}$ Secondly, in Roman Palestine, local cults of Kore are attested, at Sebaste, Neapolis, and Gaza, whereas there is no clear evidence for a cult of Demeter, unless it was combined with worship of Kore. ${ }^{29}$

\section{Kore on coins of Neapolis}

On coins of Neapolis Kore is not yet attested with certainty. But, in light of the above arguments, and having looked at the Neapolis tetradrachms, one can find her among the rich and varied bronze coinage of Neapolis which still has many an unidentified "female figure standing." I will briefly comment on three types here.

Coin under Volusian (Fig. 8): Kore, wearing a kalathos, stands to the left of the image, slightly turned toward the right. ${ }^{30}$ Largely the same costume and posture as above, with similar ambiguity about the right arm as before: a bulge that looks like the right forearm is on her chest, while the spindly right arm appears to be raised and holding the snake-entwined torch. It seems that this engraver, or the artist who made his model, misunderstood the image and depicted the right hand resting on her collarbone, holding the hem of her robe in a gesture reminiscent of Nemesis. ${ }^{31}$ The left hand holds grain ears or poppies above a cista mystica. Further right, Nike holds up an image of Mount Gerizim.

Coin minted roughly contemporaneously under Trebonianus Gallus (Fig. 9); similar reverse as before. ${ }^{32}$ Here the engraver took the logical next step: having determined that the right arm was resting on the chest, he considered the torch free-standing and decided

Dedication to Kore at Neapolis: Torrey 1926, 244-46; Seyrig 1932, 357. Gaza: from the 4th-c. CE biography of the bishop Porphyry of Gaza written by Mark the Deacon: Grégoire and Kugener 1930, 64. Ovadiah and Mucznik 2009, 81-82, cite two inscriptions from Skythopolis as evidence for the worship of Demeter there, but the first almost certainly refers to a name starting with Demet-, while the second just names a "queen of all the earth."

30 RPC 9.2156 ("Demeter(?)"). No example in the Sofaer Collection.

31 Nemesis, too, features on the coins of Neapolis: Meshorer 2013, nos. 226-27, 231.

32 Meshorer 2013, no. 230 (“Demeter?”); RPC 9.2138 (“Demeter(?)”). 


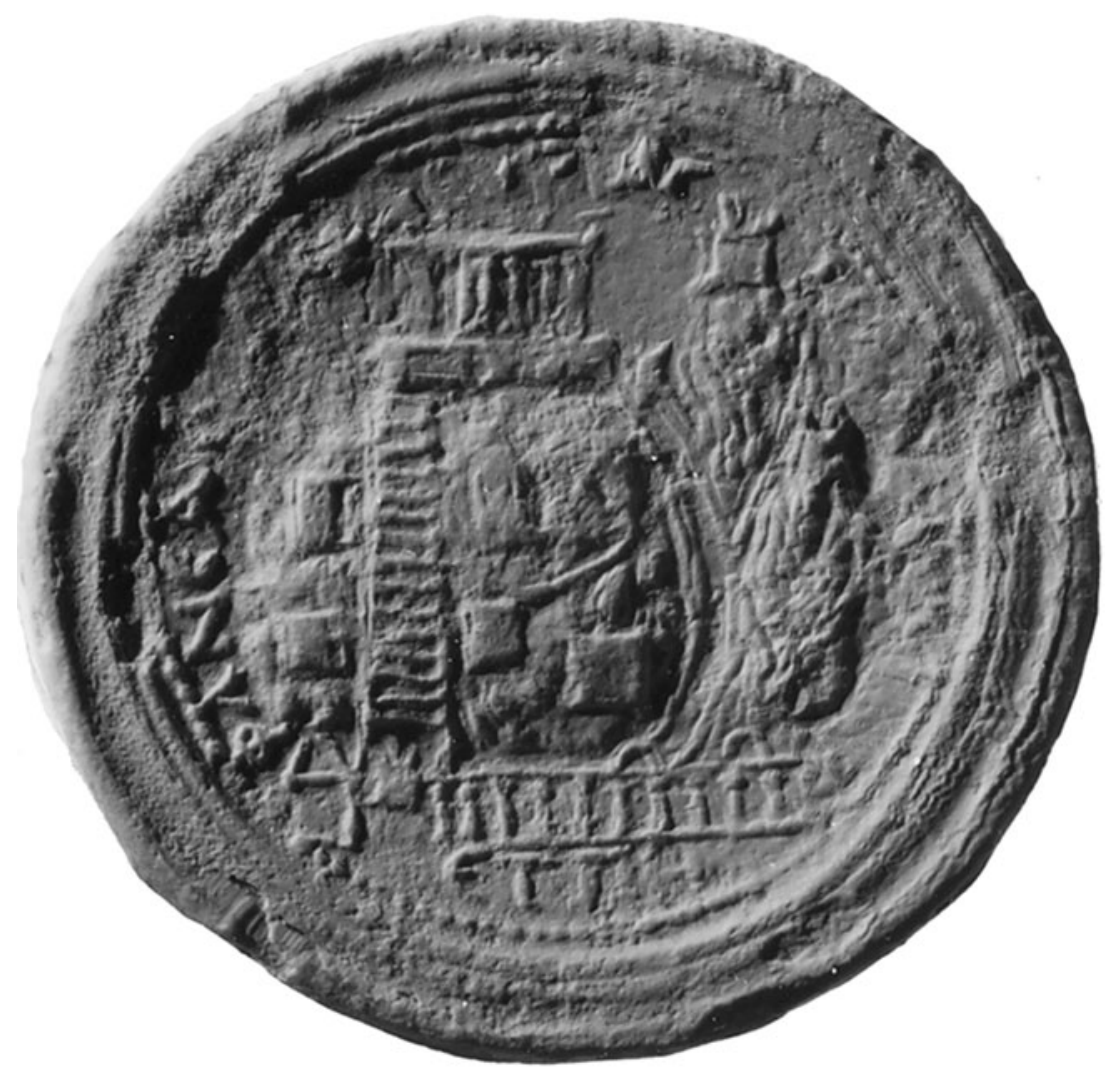

Fig. 11. Bronze medallion of Neapolis minted under Antoninus Pius, 159/60 CE (54 mm, $53.6 \mathrm{gm})$, shown twice actual size in print. Reverse: panoramic view of Mount Gerizim. (From the Sofaer Collection at The Israel Museum. Photo (C) American Numismatic Society. Reprinted with permission.)

to move it into the center of the composition behind the cista. This made for a more balanced and economical composition, though a far cry from the original intent of the image.

Coin under Trebonianus Gallus (Fig. 10): Kore appears as before, but in a frontal position and framed by the aedicula façade; to her left is the cista mystica. ${ }^{33}$ Much of the right arm appears to be missing once again, for the same reasons as above. ${ }^{34}$ Further left, Nike holds up an image of Mount Gerizim.

\section{Identification: The altar on Mount Gerizim}

The image on the tetradrachms minted under Caracalla restores from oblivion a public monument of Neapolis, a monumental altar decorated with images of Tyche, Ephesian Artemis, and Kore. Considering the protagonist of this group, one can speak of a truly civic monument, with pride of place given to the patron goddess of the community.

33 Meshorer 2013, no. 225 ("female figure standing"); RPC 9.2152 (“Demeter(?)").

34 One rare example from a different die (Heritage Auction 3018, lot 20453, sold September 5, 2012), though quite worn, appears to show the raised right arm with the hand holding an object, as well as traces of a long shaft below the right elbow. 


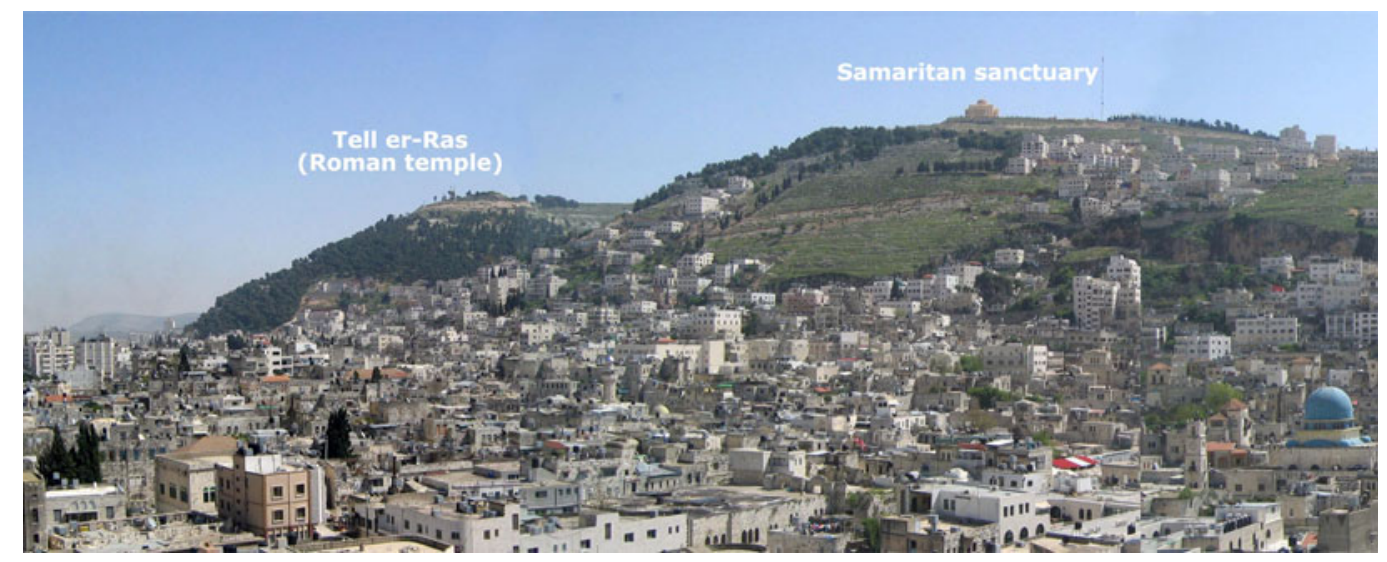

Fig. 12. View from Nablus towards the southeast, with the twin peaks of Mount Gerizim. (Photo from https:// commons.wikimedia.org/wiki/File:Nablus_panorama.jpg; licensed under a Creative Commons Attribution-Share Alike 1.0 Generic License (https://creativecommons.org/licenses/by-sa/1.0/deed.en); text added by author.)

There can be no doubt that this was a key monument in the city of Neapolis. Its significance can be gauged from perusing the imagery on Neapolis tetradrachms in toto. The emission of Caracalla reviewed here includes Mount Gerizim and three different kinds of altars (small, large, and extra-large) all issued contemporaneously and, in one instance, even linked by a shared obverse die (Figs. 1-4). These three versions no doubt all refer to the same monument, with the largest version a one-issue deluxe type offering more detail. But there is more to it: the altar is the mintmark of Neapolis tetradrachms. Very rare special editions (like the Mount Gerizim issue) aside, the altar was the only symbol that the Neapolis mint invariably picked to represent the city on its silver currency. ${ }^{35}$ Where Tyre used the club of Melqart as the civic emblem on its tetradrachms, and Sidon an image of Europa on the bull, Neapolis had its altar. The importance of this altar as a civic icon can therefore hardly be overstated.

Where in the city might this altar have stood? The civic coins depict many altars, usually at the center of narrative scenes surrounded by figures gathered for sacrifice. By far the most prominent altar is in the landscape images of Mount Gerizim reproduced on countless Neapolis coins. ${ }^{36}$ These iconic vignettes show the twin peaks of Mount Gerizim separated by a meandering wadi, the left peak crowned by the Temple of Zeus, the right one by a smaller structure. This is sometimes interpreted as a smaller temple, ${ }^{37}$ but usually considered an altar. The latter view is certainly correct, as best illustrated by one exceptionally detailed coin from the Sofaer Collection (Fig. 11). This gigantic medallion (54 mm, $53.6 \mathrm{gm})$ minted under Antoninus Pius shows on the second peak not a temple but an altar: a cubic structure, with no decoration, columns, or openings, but with clearly visible flames of a sacrifice on top. ${ }^{38}$

Prieur and Prieur 2000, nos. 1303-38, 1699-1710.

36 Meshorer 2013, nos. 14-15, 19-23, etc.; Tameanko 2008; Evans 2011; Lichtenberger 2017, 207-8.

37 Meshorer 2013, 49, but correctly described at no. 14.

38 Meshorer 2013, no. 19: "the largest medallion ever struck in the region." It should also be noted that the Antonine coins (and only they) show right next to the temple another, smaller altar, 


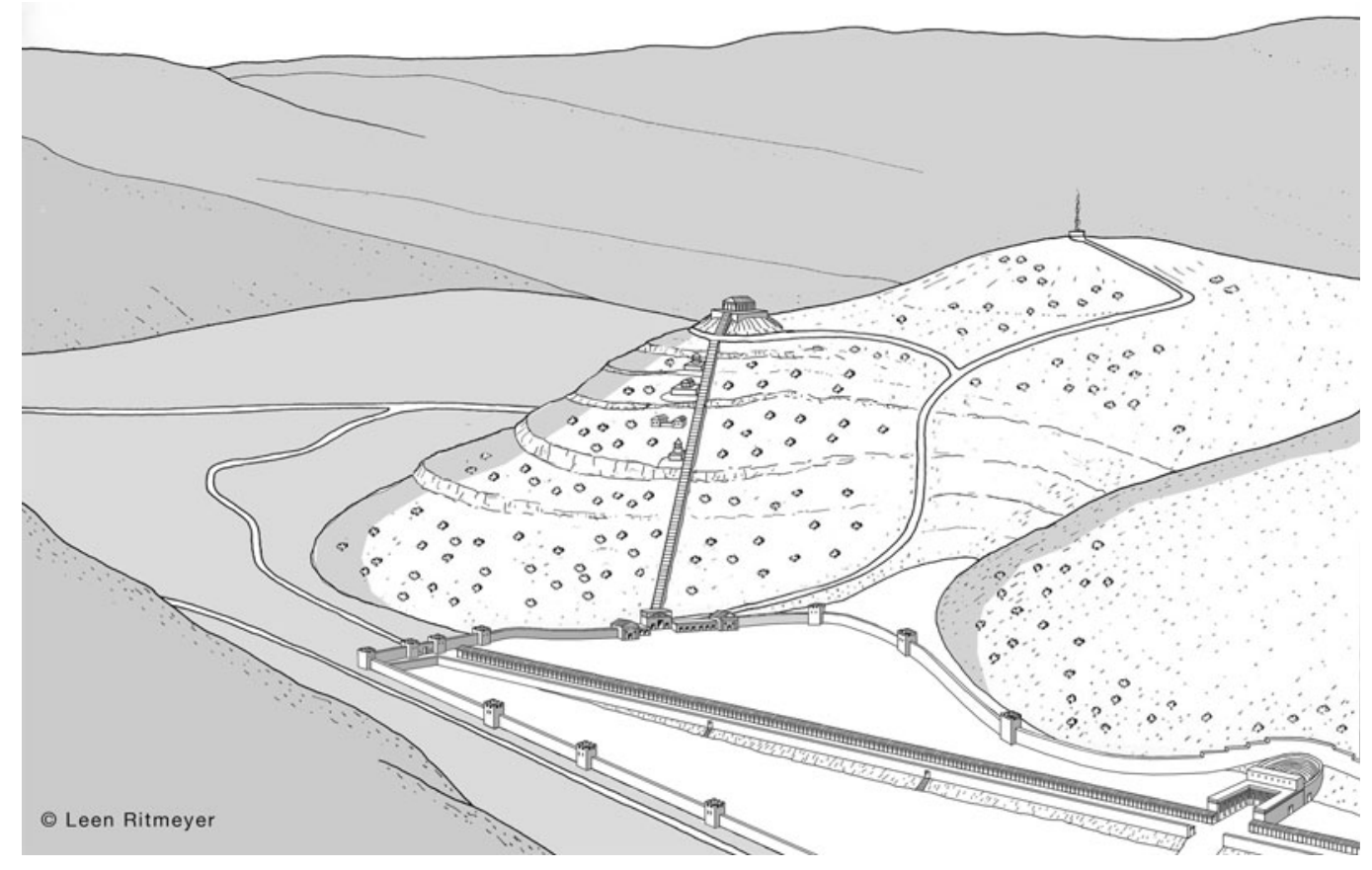

Fig. 13. Reconstruction drawing of the twin peaks of Mount Gerizim in Roman times, based on the coin images and archaeological evidence. (Courtesy L. Ritmeyer.)

There is good reason to believe that this altar is the monument shown on the Caracalla tetradrachms. For a monument to be made the civic emblem on the precious silver coinage produced at Neapolis, it had to be a landmark of prime importance in the cityscape. None would be better suited than the altar always shown in the iconic landscape of Mount Gerizim.

The numismatic context, too, supports this identification. While the altar was the mintmark of choice of the Neapolis tetradrachm mint throughout its active time, it is almost always the indistinct tiny version that is shown. Only once did the mint produce the deluxe edition celebrating the altar on its own, for the emission illustrated in Figures 1-4. The same emission included the equally rare and spectacular type showing Mount Gerizim on the reverse, the civic icon par excellence. While the image of Mount Gerizim had already featured on bronzes from the time of Antoninus Pius, there is something different and significant in the way it is shown on the tetradrachm. Here for the first time the landscape does not fill the whole picture but is fitted in a circle and is carried by an eagle. This is a new mode of representation with an added level of abstraction. The view of Mount Gerizim has ceased to be a panorama of the actual landscape and become something akin to a miniature model, a tangible object in itself, with a defined size, weight, and extension. In other words, here for the first time the panoramic view of Mount Gerizim becomes a true "icon." 39

placed curiously behind the temple (i.e., to its right). On the medallion in Fig. 11 it adjoins the temple podium; other coins show it on the podium.

Well observed by Evans 2011, 173, though only referencing bronze coins. 


\section{A Roman altar on Mount Gerizim}

This new way of conceiving and representing Mount Gerizim was to become the norm. The Gerizim "icon" next appears on bronzes under Elagabalus, tellingly shown side by side and on equal footing with the sacred baetyl of Emesa. ${ }^{40}$ The icon is here unambiguously presented as a cult image. Then, starting with Philip the Arab, the Gerizim icon becomes ubiquitous on reverses. ${ }^{41}$ In the last 10 years of minting, from Philip in 244 CE until $253 \mathrm{CE}$, when minting ceased under Volusian and Gallus, the mint churned out a vast number and variety of coins. Of the 118 types listed in the Sofaer catalog for this period, 104 depict Mount Gerizim, always in the shape of the "icon" and added to all kinds of narrative scenes with various deities and emperors. Gerizim is often hovering on top of the scene, or held up by an eagle, Victory, Tyche, or the she-wolf (Figs. 8-10). Neapolis is unique in this respect. There is no other city coinage where an image of its natural or urban environment is reinterpreted in this peculiar fashion. ${ }^{42}$ Exploring the world of ideas behind this peculiar visual habit would be a worthwhile subject of study. What does this abstraction mean? Was the mountain itself an object of pagan worship? ${ }^{43}$ What matters for the present context is that it is on these Caracalla tetradrachms that the Mount Gerizim panorama is first "iconicized."

This is the ideological framework to think with when looking at this tetradrachm emission which juxtaposes Mount Gerizim with three types of altars (or, rather, three versions of the same altar) and even shares an obverse die with them. The other type with the enlarged mintmark, the deluxe altar type, in particular, comes from the same ideological mold. Both belong to that very rare category of tetradrachms that break the monotonous design formula of Syro-Phoenician tetradrachms (imperial portrait, names, and titles; Roman eagle; miniscule mintmark). Generic symbolism and Roman imperial messaging are here complemented with distinct and specific symbols that strike an unusually local and patriotic tone. Mount Gerizim and the monumental altar which puts the Tyche of Neapolis front and center go hand in hand; they both celebrate the iconic sacred landscape of the city. These reverses were thus closely linked thematically and topographically, presenting the twin peaks of Mount Gerizim and its landmarks, the temple and the altar. The latter, which is usually reduced to a miniature shape in the landscape, in this emission receives its due share of prominence.

\section{Location}

Where on Mount Gerizim was the altar located? The coin images, which of course only show a shorthand version of the ancient cityscape as it must have looked at the time, give some indication of its position (Figs. 1, 8-11). The twin peaks on the coins are those one

40 Meshorer 2013, nos. 102-3. Evans 2011, 178, interprets this pairing with the Emesan baetyl as "making the mountain a baetyl of similar power and reverence."

$41 \quad$ On the coinage under Philip, see Harl 1984; Sandberg 2019.

42 Evans 2011, 180, though I disagree that this icon is "a replacement for the figure or bust of Tyche" (178). The compositions of these scenes with the Gerizim icon would not fit Tyche and seem to be a whole genre of their own.

43 This iconization of Mount Gerizim could be a distant echo of Samaritan beliefs among the Neapolitan population, at a time when Samaritan worship on Mount Gerizim was suppressed and the community had disappeared from view: "The Samaritans became deeply assimilated in the Roman period: they took Greek and Latin names, adopted Roman culture and, seemingly, the Roman pagan religion as well" (Magen 2009, 1:360). 
would see from ancient Neapolis (and modern Nablus) looking south (Figs. 12-13): to the left Tell er-Ras (831 m asl), where excavations between 1962 and 1973 uncovered the remains of a Roman-period podium temple, $14 \mathrm{~m}$ by $21 \mathrm{~m}$, which could well match the coin images depicting a tetrastyle temple. ${ }^{44}$ Inscriptions from the site confirm that the temple was dedicated to Zeus Olympios. ${ }^{45}$ This is the temple that various sources also ascribe to Zeus Hellenios, Zeus Xenios, and Zeus Hypsistos.

The neighboring hill with the altar, which the coins depict to the right of the temple hill, has yet to be identified. On the Antonine coins and medallions, this hill is consistently shown taller than the temple hill; later on, the two are depicted as roughly the same height. As Tell er-Ras with the Roman temple is to the southeast of Neapolis, "to the right" when seen from the city would have to be south, southwest, or west of the temple. One area that fits this description is the main peak of Mount Gerizim ( $881 \mathrm{~m}$ asl) to the south of Tell er-Ras, where excavators have uncovered the remains of an architectural complex which they identify as the famous Samaritan sanctuary, the heart of Samaritan religion, attested in the pages of Josephus and many other sources (Figs. 12-13). ${ }^{46}$ The two main building phases of this complex have been dated by Y. Magen, the director of large-scale excavations on site from 1983 to 2008, to the Persian and Seleucid periods. The Persian compound of 98 $\mathrm{m}$ by $96 \mathrm{~m}$ was built in the 5th c. BCE, then overbuilt in the 2nd c. BCE with a complex measuring $212 \mathrm{~m}$ by $136 \mathrm{~m}$. No temple or altar was found, ${ }^{47}$ but enormous quantities of finds (including 500 inscriptions, 16,000 coins, and over 400,000 animal bones) indicate intense frequentation and ritual activity over long periods of time. The finds also provide a chronological framework, suggesting that, after its destruction by the Hasmonaeans at the end of the 2nd c. BCE, the site was left abandoned until the construction of a monumental church inside the compound in the 5th c. CE.

The excavations have hence yielded no archaeological evidence for the altar or indeed any activity or occupation of the hilltop all through Roman imperial times. Despite this, there is evidence, beside the coin images, to suggest that the site remained a religious hub throughout the Roman imperial period. For the Samaritans, Mount Gerizim remained the sacred place during this time. It is here that they clashed with Roman legions in $67 \mathrm{CE}$ : the troops of Vespasian, upon encountering a gathering of Samaritans on the hilltop and determining it to be a dangerous incipient revolt, besieged and ascended the mountain and, according to Josephus, killed 11,600 Samaritans. ${ }^{48}$ No building - synagogue or otherwise - is mentioned in this context. But literary sources show that in the reign of Constantine I (r. 324-37) the Samaritans were still worshiping on Mount Gerizim and may have erected a sacred building at that time. ${ }^{49}$ When in the 5 th c. CE the emperor Zeno built the Theotokos church on the summit, multiple sources attest that it was built on the site of a Samaritan synagogue. ${ }^{50}$

Bull 1968; Magen 2009, 1:236-68; Ovadiah and Turnheim 2011, 75-80.

E.g., SEG 7.97.

Magen 2008a; Pummer 2016a, 79-91.

There is some debate as to whether there ever was a temple or only an altar: see Pummer 2016b.

Joseph, BJ 3.307-15. My thanks to one of the anonymous JRA reviewers for this reference.

Magen 2008b, 245-49.

Malalas, Chron. 15.382-83. Other early Christian writings: Pummer 2002, 257-58, with n. 40.

Samaritan sources: Stenhouse 1985, 240. Though redacted in the Middle Ages, Samaritan 


\section{A Roman altar on Mount Gerizim}

These late sources show that the archaeological record that has emerged from the excavations on Mount Gerizim does not tell the whole story: the site was not entirely deserted after the destruction of the Samaritan temple by John Hyrcanus. Like the Samaritan synagogue, for which there seems to be no tangible archaeological evidence, the remains of our Roman-period altar, too, may have been obliterated by the construction of Zeno's church. In sum, though the Roman-period occupation phases of Mount Gerizim still elude us archaeologically, this hilltop is very likely the site where our altar once stood (as shown in the new reconstruction drawing, Figure 13). Its existence and approximate location are proven beyond doubt by Neapolitan coins starting in the reign of Antoninus Pius, though its exact location is yet to be determined.

\section{Conclusions}

Mount Gerizim and its monuments have long been known from the famous panoramic views on the bronze coinage of Roman Neapolis. As this study has shown, the twin peaks with the temple and the altar were also celebrated on newly attributed Caracalla tetradrachms from the mint of Neapolis. Among this tetradrachm emission, the previously unknown altar type gives us for the first time a close-up view of the monument, with details of its design and decoration, and thus rescues this civic icon from oblivion.

With their oversized mintmarks, the Caracalla tetradrachms of Neapolis with images of Mount Gerizim and the monumental altar are rare special editions that stand out from the monotonous uniformity of the tetradrachm formula. In a currency that is normally exclusively geared to propagating imperial themes, these exceptional types appropriate the design to promote local messages. The imagery boldly celebrates Neapolis and its community and proudly asserts local identities through its iconic urban landmarks.

\section{References}

Amandry, M. 2016. "Sur certains tétradrachmes provinciaux de Syrie." In Syria Supplement 3: Henri Seyrig (1895-1973), ed. F. Duyrat, 177-82. Beirut: IFPO.

Baldus, R. 2001. Sylloge Nummorum Graecorum Deutschland. Staatliche Münzsammlung München. Vol. 28, Syrien. Nicht-königliche Prägungen. Munich: Hirmer.

Bellinger, A.R. 1940. The Syrian Tetradrachms of Caracalla and Macrinus. New York: ANS.

Bull, R.J. 1968. “The excavation of Tell er-Ras on Mt. Gerizim.” Biblical Archaeologist 31: 58-72.

Butcher, K. 2003. Roman Syria and the Near East. London: British Museum Press.

Butcher, K. 2004. Coinage in Roman Syria: Northern Syria, 64 BC-AD 253. London: Royal Numismatic Society.

Donaldson, T. L. 1859. Architectura Numismatica: Architectural Methods of Classical Antiquity. London: Day \& Son.

Evans, J. DeRose. 2011. “From mountain to icon: Mount Gerizim on Roman provincial coins from Neapolis, Samaria." NEA 74: 170-82.

Farhi, Y. 2007-8. "The coinage of Diospolis (Lod) in the Roman Period." INJ 16: 139-63.

Fleischer, R. 1973. Artemis von Ephesos und verwandte Kultstatuen aus Anatolien und Syrien. Leiden: Brill. Gersht, R. 1984. "The Tyche of Caesarea." PEQ 116: 110-14.

Grégoire, H., and M.-A. Kugener, eds. and trans. 1930. Marc le Diacre. Vie de Porphyre, évêque de Gaza. Paris: Les Belles Lettres.

Harl, K. W. 1984. “The coinage of Neapolis in Samaria.” ANSMN 29: 61-97.

chronicles incorporate older traditions. My thanks to one of the anonymous $J R A$ reviewers for this information. 
Kapossy, B. 1988. “Ein unbekanntes Tetradrachmon des Caracalla." SchwMbll 38: 38-40.

Kapossy, B. 1993. Sylloge Nummorum Graecorum. Schweiz II. Münzen der Antike: Katalog der Sammlung Jean-Pierre Righetti im Bernischen Historischen Museum. Bern: Haupt.

Kropp, A. J. M. 2011. "Anatomy of a Phoenician goddess: The Tyche of Berytus (Beirut) and her acolytes." JRA 24: 389-407.

Kropp, A. J. M. 2021. “The tetradrachm mint of Neapolis (Samaria): New attributions and the phantom mint of Byblos." NC 181. In press.

Lichtenberger, A. 2017. "Coin iconography and archaeology: Methodological considerations about architectural depictions of city coins of Palestine." In Expressions of Cult in the Southern Levant in the Greco-Roman Period: Manifestations in Text and Material Culture, ed. O. Tal and Z. Weiss, 197-220. Brussels: Brepols.

Magen, Y. 2008a. "Gerizim." In New Encyclopedia of Archaeological Excavations in the Holy Land, vol. 5, ed. E. Stern, 1742-48. Jerusalem: Israel Exploration Society.

Magen, Y. 2008b. Mount Gerizim Excavations, Volume II: A Temple City. Judea \& Samaria Publications 8. Jerusalem: Israel Antiquities Authority.

Magen, Y. 2009. Flavia Neapolis: Shechem in the Roman Period. 2 vols. Jerusalem: Israel Antiquities Authority.

Magness, J. 2001. "The cults of Isis and Kore at Samaria-Sebaste in the Hellenistic and Roman periods." HTR 94: 157-77.

Meshorer, Y. 2013. Coins of the Holy Land: The Abraham and Marian Sofaer Collection. New York: ANS.

Nurpetlian, J. 2014. "Damascene tetradrachms of Caracalla." AJN 26: 187-98.

Nurpetlian, J. 2020. Coinage in the Orontes Valley of Syria (1st c. BC-3rd c. AD). London: Royal Numismatic Society.

Ovadiah, A., and S. Mucznik. 2009. Worshipping the Gods: Art and Cult in Roman Eretz Israel. Leiden: Alexandros.

Ovadiah, A., and Y. Turnheim. 2011. Roman Temples, Shrines and Temene in Israel. Rome: Bretschneider.

Price, M. J., and B. Trell 1977. Coins and their Cities. London: Vecchi.

Prieur, M., and K. Prieur. 2000. A Type Corpus of the Syro-Phoenician Tetradrachms and Their Fractions: From $57 B C$ to $A D$ 253. London: CNG.

Pummer, R. 2002. Early Christian Authors on Samaritans and Samaritanism: Texts, Translations and Commentary. Texts and Studies in Ancient Judaism 92. Tübingen: Mohr Siebeck.

Pummer, R. 2016a. The Samaritans: A Profile. Grand Rapids: Eerdmans.

Pummer, R. 2016b. "Was there an altar or a temple in the sacred precinct on Mt. Gerizim?" Journal for the Study of Judaism in the Persian, Hellenistic, and Roman Period 47: 1-21.

Sandberg, L. 2019. "The coinage of Flavia Neapolis under Philip I: The Roman connection." Israel Numismatic Research 14: 141-52.

Seyrig, H. 1932. “Notes sur le culte de Déméter en Palestine (antiquités syriennes 10)." Syria 13: 355-60.

Seyrig, H. 1962. "Divinités de Ptolémais (antiquités syriennes 80)." Syria 39: 193-207.

Stenhouse, P. 1985. The Kitāb al-tarīkh of Abū 'l-Fath: Translated into English with Notes. Sydney: University of Sydney.

Tameanko, M. 2008. “The temple on Mount Gerizim.” Celator 22: 6-20.

Torrey, C. 1926. "A specimen of old Aramaic verse." JAOS 46: 241-47.

Wroth, W. 1910. Catalogue of the Greek Coins of Galatia, Cappadocia and Syria. London: British Museum. 